Open Journal System

Volume 1 no 12020

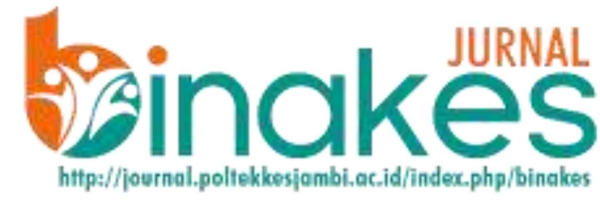

\title{
PENINGKATAN PENGETAHUAN DAN KETRAMPILAN MENYIKAT GIGI DENGAN MEDIA POSTER PADA MURID MADRASAH DINIYAH TAKMILIYAH AL-BANAT KABUPATEN MUARO JAMBI
}

\author{
Sukarsih $^{1}$, Aida Silfia ${ }^{1}$ \\ ${ }^{1}$ Jurusan Keperawatan Gigi Poltekkes Kemenkes Jambi
}

\section{KONTAK PENULIS}

sukarsihjambi@gmail.com

DOI:

https://doi.org/10.35910/ binakes.v1i1.370

\section{Kata Kunci:}

menyikat gigi; media poster; madrasah

\section{ABSTRAK}

Latar Belakang: Hasil Riskesdas tahun 2018 sebesar 41,4\% anak berusi 10-14 tahun di Indonesia memiliki masalah pada kesehatan gigi dan mulutnya dan sebesar $37,7 \%$ penduduk di Provinsi Jambi memiliki masalah kesehatan gigi dan mulut, dan $96,5 \%$ anak usia $10-14$ tahun di Indonesia menyikat gigi setiap harinya, dan 1,4\% yang menyikat gigi dengan waktu yang tepat.

Metode: Murid kelas I, II, III Madrasah Diniyah Takmiliayah Al-Banat Kab. Muaro Jambi yang berjumlah 68 orang belum pernah mendapatkan penyuluhan kesehatan gigi dan mulut dari petugas kesehatan. Tujuan pengabdian masyarakat untuk meningkatkan pengetahuan dan keterampilan cara menyikat gigi dengan media poster pada murid Kelas I, II, III Madrasah Diniyah Takmiliayah Al-Banat Kab. Muaro Jambi

Hasil: adanya peningkatan pengetahuan cara menyikat gigi pada kriteria tinggi sebelum diberi penyuluhan sebesar $29,41 \%$ menjadi $82,35 \%$ sesudah diberi penyuluhan dengan menggunakan media poster. Ada peningkatan keterampilan cara menyikat gigi kriteria baik sebanyak $25 \%$ menjadi $86,76 \%$ setelah diberi penyuluhan cara menyikat gigi menggunakan media poster

Kesimpulan: Terjadi peningkatan pengetahuan acra menyikat gigi setelah diberikan penyuluhan dengan media poster
Keywords:

brushing teeth;; media poster; madrasah

\section{ABSTRACT}

Background: The results of Riskesdas in 2018 reported 41.4\% of children aged 10-14 years in Indonesia had problems with their teeth and mouth health, and $37.7 \%$ of the population in Jambi Province had dental and oral health problems, and 96.5\% of children aged 10-14 years in Indonesia brushed their teeth every day, and $1.4 \%$ of children brushed their teeth with the right time.

Methods: The first, second, third grade of Madrasah Diniyah Takmiliayah Al-Banat in Muaro Jambi regency, totaling 68 people, have never received dental and oral health education from health workers. Therefore, this community service aimed to increase knowledge and skills on how to brush teeth properly with poster media for the students of the first, second, and third grade in Madrasah Diniyah Takmiliayah Al-Banat in Muaro Jambi regency.

Results: showed an increase in knowledge on how to brush teeth at high criteria before counseling from $29.41 \%$ to $82.35 \%$ after counseling by using poster media. Additionally, there was an increase in skills on how to brush teeth with good criteria by $25 \%$ to $86.76 \%$ after counseling on how to brush teeth using poster media

Conclusion: There was an increase on knowledge to brush the teeth after education using meda poster 


\section{PENDAHULUAN}

Pemeliharaan kesehatan gigi dan mulut sangat penting untuk memperoleh kesehatan tubuh kita. Pemeliharaan gigi pada masa anakanak sangat penting karena kondisi gigi susu (gigi decidur) sangat menentukan keadaan gigigigi penggantinya. Perawatan kesehatan gigi dan mulut pada anak usia dini sangatlah penting karena gigi rentan sekali terhadap gangguan kesehatan gigi dan mulut, apabila tidak dicegah atau ditangani, anak yang tumbuh dewasa nantinya akan merasakan kesenjangan sosial akibat bentuk giginya yang kurang baik. Penyikatan gigi merupakan salah satu cara untuk membersihkan gigi dan mulut yang harus dilakukan dengan teknik yang benar sehingga dapat menghilangkan plak penyebab penyakit gigi dan mulut.

Menurut hasil Riskesdas tahun 2018 sebesar $41,4 \%$ anak berusia 10-14 tahun di Indonesia memiliki masalah pada kesehatan gigi dan mulutnya, sebesar $37,7 \%$ penduduk di Provinsi Jambi memiliki masalah kesehatan gigi dan mulut, dan $96,5 \%$ anak usia $10-14$ tahun di Indonesia menyikat gigi setiap harinya, dan 1,4\% yang menyikat gigi dengan waktu yang tepat. Penduduk di Provinsi Jambi yang menyikat gigi setiap hari $96,4 \%$ dan $1,0 \%$ yang menyikat gigi di waktu yang tepat (Kemenkes RI, 2018).

Promosi kesehatan bertujuan untuk merubah perilaku seseorang. Perilaku sangat dipengaruhi oleh pengetahuan. Perilaku yang didasari pengetahuan yang benar akan lebih bertahan lama daripada perilaku yang tidak didasari pengetahuan, termasuk pengetahuan tentang cara menjaga kesehatan gigi yang benar akan sangat berpengaruh terhadap kejadian karies (Notoatmodjo, 2012). Hasil Riset Kesehatan Dasar tahun 2018 mencatat proporsi masalah gigi dan mulut sebesar $57,6 \%$ dan yang mendapatkan pelayanan dari tenaga medis gigi sebesar 10,2\%. Adapun proporsi perilaku menyikat gigi dengan benar sebesar 2,8\%.

Menurut Herijulianti, dkk (2002) penyuluhan kesehatan gigi merupakan upayaupaya yang dilakukan untuk merubah perilaku seseorang, sekelompok orang, maupun masyarakat sedemikian rupa, sehingga memiliki kemampuan dan kebiasaan berpola hidup sehat dibidang kesehatan gigi. Menurut Fitriani (2011) bahwa konsep penyuluhan kesehatan sebenarnya tidak berbeda dengan pendidikan kesehatan. Penyuluhan kesehatan adalah memberikan pengertian sebagai suatu proses perubahan, pertumbuhan dan perkembangan diri manusia menuju kepada keselarasan dan keseimbangan jasmani, rohani dan sosial dari manusia tersebut terhadap lingkungannya, sehingga mampu dan bertanggung jawab untuk mengatasi masalahmasalah kesehatannya sendiri serta masyarakat lingkungannya.

Media Poster dapat lebih efektif sebagai media penyuluhan karena lebih membantu menstimulasi indra penglihatan murid, aspek visual pada gambar-gambar poster lebih memudahkan penerimaan informasi atau materi pendidikan(Linasari, 2014). Berdasarkan observasi bahwa di Madrasah Diniyah Takmiliyah Al-Banat Jambi belum memiliki poster maupun media kesehatan lainnya disetiap kelas, sehingga pada waktu lalu penyuluhan yang dilakukan terbatas dengan metode ceramah menggunakan media papan tulis. Metode ceramah hanya melibatkan $30 \%$ dari indra sasaran penyuluhan, oleh karenanya perlu diberikan penyuluhan dengan alat bantu yang dapat membantu dan memperagakan sesuatu di dalam proses penyuluhan (Notoatmodjo, 2012).

Alat bantu penyuluhan diperlukan untuk memaksimalkan pemanfaatan indra sasaran yang ditentukan oleh tujuan penyuluhan karena setiap alat bantu memiliki intensitas yang berbeda. Jika tujuan penyuluhan pada aspek pengertian atau pengetahuan maka pesan yang disampaikan cukup dengan lisan namun harus menggunakan alat peraga yang dapat menarik minat sasaran penyuluhan. Untuk meningkatkan pengetahuan kesehatan gigi dan mulut murid Madrasah Diniyah Takmiliyah Al-Banat diperlukan penyuluhan kesehatan gigi dengan media poster sebagai alat bantu yang dapat menarik minat murid dan memaksimalkan penggunaan indra murid, salah satunya adalah media poster berupa gambar yang diharapkan lebih menarik minat murid dari aspek visual (Notoatmodjo, 2012). 
Politeknik kesehatan Jambi merupakan unit pelaksana teknis Kementerian Kesehatan yang berada di bawah Badan Pengembangan dan Pemberdayaan Sumber Daya Manusia Kesehatan (BPPSDMK). Poltekkes Jambi sebagai institusi pendidikan tenaga kesehatan memiliki tugas dan fungsi melaksanakan Tridarma Perguruan Tinggi yaitu menyelenggarakan pendidikan, penelitian dan pengabdian masyarakat. Pengabdian masyarakat di bidang kesehatan gigi dalam hal ini dilaksanakan pada murid Madrasah Diniyah Takmiliyah Al-Banat Desa Penyengat Olak Kab. Muaro Jambi. Adapun alasan dilakukan pengabdian masyarakat pada Madrasyah tersebut karena belum pernah ada pelayanan kesehatan gigi dan mulut dari tenaga kesehatan atau yang lainnya, hal ini disebabkan oleh jam belajar murid-murid pada jam 14.00 s/d 16.30 WIB.

Profil Madrasah Diniyah Takmiliyah Al-Banat yang lokasinya di Jl. Lintas Timur RT.15, RW.08 Desa Penyengat Olak Kabupaten Muaro Jambi Provinsi Jambi, merupakan wilayah kerja Puskesmas Penyengat Olak. Jumlah murid Madrasah Diniyah Takmiliyah Al-Banat Desa Penyengat Olak Kab. Muaro Jambi tahun 2019 sebanyak 170 murid. Murid kelas I $=33$ orang, kelas II $=12$ orang dan kelas III = 23 orang, Madrasah Diniyah Takmiliyah Al-Banat dengan jumlah guru 13 orang.

\section{METODE}

Survei awal ke Madrasah Diniyah Takmiliyah Al-Banat Penyengat Olak Kab. Muaro Jambi dilakukan tanggal 05 Oktober 2019. Pertemuan dengan Kepala Sekolah untuk menyepakati pelaksanaan pengabdian kepada masyarakat. Penyusunan proposal kegiatan pengabdian kepada masyarakat, dilanjutkan pengurusan izin administrasi kepada pihak terkait.

Persiapan instrumen/alat dan bahan pengabdian kepada masyarakat, antara lain: kuesioer pre test dan post test, poster, beserta sikat gigi dan pasta gigi, handuk, ember, tisu, antiseptik, dan air mineral untuk kumur- kumur. Membentuk tim dan kalibrasi pelaksanaan kegiatan pengabdian masyarakat.

Tahap pelaksanaan. Pada awal kegiatan dilakukan pre test dengan cara pengisian kuesioner tentang pengetahuan dan keterampilan cara menyikat gigi pada murid kelas I, II, III Madrasah Diniyah Takmiliyah Al-Banat Penyengat Olak Muaro Jambi.

Penyuluhan menggunakan media poster dengan cara ceramah, demonstrasi dan praktek di lapangan cara menyikat gigi pada murid kelas I, II, III Madrasah Diniyah Takmiliyah Al-Banat Penyengat Olak Kab. Muaro Jambi Evalausi kegiatan dilakukan dengan post test dengan cara pengisian kuesioner pengetahuan cara menyikat gigi dan observasi keterampilan cara menyikat gigi pada murid kelas I, II, III Madrasah Diniyah Takmiliyah Al-Banat Penyengat Olak Kab. Muaro Jambi.

Tahap Penyusunan laporan. Pengolahan data dengan tahapan mengedit data, mengkode data untuk pengetahuan dibagi dua kriteria Tinggi jika jawaban benar $(>50 \%)$ dan rendah $(\leq 50 \%)$, dan observasi keterampilan menyikat gigi dibagi dua kriteria baik $(>50 \%)$ dan kurang baik $(\leq 50 \%)$ selanjutnya entri data dan cleaning data. Analisis data, untuk melihat gambaran distribusi frekuensi dari pengetahuan dan keterampilan sebelum dan sesudah penyuluhan dan demonstrasi cara menyikat gigi serta melihat peningkatan setelah dilakukan intervensi.

Evaluasi yang dilaksanakan pada hari Rabu tanggal 2 November 2019 dengan melakukan pre tes sebelum penyuluhan dan post tes setelah penyuluhan untuk tolok ukur keberhasilan peningkatan pengetahuan dalam menyikat gigi. Untuk keterampilan murid dalam menyikat gigi di evaluasi dengan cara seluruh murid kelas I, II, III sebelum menyikat gigi di beri disklosing solution dari pewarna kue warna merah (Handayatun dkk, 2020) dengan menggunakan cotton bud, lalu menyikat gigi bersama seluruh murid kelas I, II, III Penyengat Olak Kab. Muara Jambi. 


\section{HASIL DAN PEMBAHASAN}

Kegiatan pengabdian masyarakat yang dilakukan di Madrasah Diniyah Takmiliyah AlBanat terlaksanan tanpa kendala yang berarti. Guru dan murid sangat antusias mengikuti seluruh rangkaian kegiatan. Kegiatan pengabdian kepada masyarakat dilaksanakan tanggal 23 Oktober 2019 pada murid kelas I, II, III Madrasah Diniyah Takmiliyah Al-Banat Penyengat Olak Kab. Muara Jambi. Tempat kegiatan di Jl. Lintas Timur, Desa Penyengat Olak, Kec. Jambi Luar Kota Kab. Muara Jambi.Waktu kegiatan mulai jam 14.00 WIB dan selesai 16.30 WIB. Tempat kegiatan penyuluhan dilakukan di dalam kelas, sedangkan praktek menyikat gigi dilakukan di halaman kelas I, II, III Madrasah Diniyah Takmiliyah Al-Banat Penyengat Olak tersebut. Transportasi yang digunakan untuk ke lokasi Madrasah Diniyah Takmiliyah Al-Banat Penyengat Olak adalah dengan mengendarai kendaraan roda empat. Alat yang digunakan dalam kegiatan pengabdian masyarakat ini adalah, papan tulis, panthom gigi dan sikat gigi, poster, pasta gigi, handuk kecil, gelas kumur, tisue, dan air mineral untuk kumurkumur dalam pelaksanaan kegiatan. Untuk menyikat gigi murid kelas I, II, III Madrasah Diniyah Takmiliyah Al-Banat Penyengat Olak, semua murid dan guru diberi sikat gigi, pasta gigi, air mineral dan handuk. Sedangkan pihak sekolah diberi 2 (dua) buah phoster tentang cara menyikat gigi dan memelihara kesehatan gigi dan mulut, sebagai cinderamata yang bisa dimanfaatkan murid-murid untuk belajar cara menyikat gigi.

Pihak yang terlibat dalam kegiatan pengabdian ini antara lain : tim pengabdi, tim pembantu seperti : Dosen Jurusan Keperawatan Gigi, Mahasiswa Keperawatan gigi, Kepala Sekolah Madrasah Diniyah Takmiliyah Al-Banat Penyengat Olak, para guru dan murid kelas I, II, III Madrasah Diniyah Takmiliyah Al-Banat Penyengat Olak kabupaten Muara Jambi.

Berdasarkan hasil kegiatan pengabdian kepada masyarakat dari pengisian kuesioner yang diberikan sebelum dan sesudah penyuluhan dan demonstrasi cara menyikat gigi yang baik dan benar pada murid kelas I, II,
III Madrasah Diniyah Takmiliyah Al-Banat Penyengat Olak Kabupaten Muara Jambi, diperoleh data sebagai berikut:

Tabel 1: Distribusi Responden Menurut Pengetahuan tentang Cara Menyikat Gigi pada Murid Kelas I, II, III Madrasah Diniyah Takmiliyah Al-Banat Penyengat Olak Kabupaten Muara Jambi Tahun 2019

\begin{tabular}{lcccc}
\hline Pengetahuan & \multicolumn{2}{c}{ Pre Test } & \multicolumn{2}{c}{ Post Test } \\
\cline { 2 - 6 } $\begin{array}{l}\text { Cara Menyikat } \\
\text { Gigi }\end{array}$ & $\mathbf{n}$ & $\mathbf{0}$ & $\mathbf{n}$ & $\mathbf{0}$ \\
Tinggi & 20 & 29,41 & 56 & 82,35 \\
Rendah & 48 & 70,59 & 12 & 17,65 \\
Jumlah & $\mathbf{6 8}$ & $\mathbf{1 0 0}$ & $\mathbf{6 8}$ & $\mathbf{1 0 0}$ \\
\hline
\end{tabular}

Hasil pada tabel 1 menunjukkan adanya peningkatan pengetahuan cara menyikat gigi kriteria tinggi $29,41 \%$ menjadi $82,35 \%$ setelah di beri penyuluhan cara menyikat gigi menggunakan media poster. Hasil ini sesuai dengan penelitian Niska (2013) yang menunjukkan peningkatan aktivitas guru dan siswa dan hasil belajar siswa pada mata pelajaran kewarganegaran. Pada kegiatan pengabdian masyarakat ini juga terjadi peningkatan pengetahuan murid madrasah dan diharapkan guru juga lebih aktiv memberikan penyuluhan pada murid setelah diberikan poster sebagai cindramata.

Demikian juga pada hasil penelitian Kusumawardani dkk (2018) pembelajaran dengan menggunakan media poster pada model kooperatif tipe STAD efektif terhadap hasil belajar matematika siswa SD kelas V Negeri Penanggulan Kendal.

Tabel 2: Distribusi Responden Menurut Keterampilan Cara Menyikat Gigi pada Murid Kelas I, II, III Madrasah Diniyah Takmiliyah AlBanat Penyengat Olak Kabupaten Muara Jambi Tahun 2019

\begin{tabular}{lcccc}
\hline Keterampilan & \multicolumn{2}{c}{ Pre Test } & \multicolumn{2}{c}{ Post Test } \\
\cline { 2 - 5 } $\begin{array}{l}\text { Cara Menyikat } \\
\quad \text { Gigi }\end{array}$ & $\mathbf{n}$ & $\mathbf{\%}$ & $\mathbf{n}$ & $\mathbf{\%}$ \\
Baik & 17 & 25 & 59 & 86,76 \\
Kurang Baik & 51 & 75 & 9 & 13,24 \\
Jumlah & $\mathbf{6 8}$ & $\mathbf{1 0 0}$ & $\mathbf{6 8}$ & $\mathbf{1 0 0}$ \\
\hline
\end{tabular}

Berdasarkan tabel 2 menunjukkan bahwa adanya peningkatan keterampilan cara menyikat gigi kriteria baik dari sebelum hanya $25 \%$ menjadi $86,76 \%$ sesudah penyuluhan cara menyikat gigi dengan media poster.

Hasil kegiatan pengabdian kepada masyarakat dari pengisian kuesioner yang 
diberikan sebelum dan sesudah penyuluhan, dapat dilihat peningkatan pengetahuan tentang cara menyikat gigi dari tabel 1 diatas menunjukkan bahwa hasil pre test tingkat pengetahuan pada murid kelas I, II, III Madrasah Diniyah Takmiliyah Al-Banat Penyengat Olak Kabupaten Muara Jambi, dengan kriteria tinggi sebanyak $29,41 \%$ dan kriteria rendah 70,59 \%, setelah diberi penyuluhan cara menyikat gigi dengan media poster dilakukan post test tingkat pengetahuan pada murid kelas I, II, III Madrasah Diniyah Takmiliyah Al-Banat Penyengat Olak Kabupaten Muara Jambi, dengan kriteria tinggi $82,35 \%$ dan kriteria rendah $17,65 \%$, keadaan ini menunjukan bahwa setelah diberi penyuluhan cara menyikat gigi dengan media poster pengetahuan murid kelas I, II, III Madrasah Diniyah Takmiliyah Al-Banat Penyengat Olak Kabupaten Muara Jambi meningkat, dari 29,41 \% menjadi 82,35\% dengan kriteria tinggi, dan $70,59 \%$ menjadi $17,65 \%$ dengan kriteria rendah. Hal ini kemungkinan murid-murid mendapatkan pengetahuan tentang menjaga kesehatan gigi dan mulutnya selain dari media poster juga media lain seperti televisi, radio, Internet, karena berdasarkan wawancara yang dilakukan pada guru ternyata murid kelas I, II, III Madrasah Diniyah Takmiliyah Al-Banat Penyengat Olak Kabupaten Muara Jambi belum pernah dikunjungi oleh tenaga kesehatan dan belum pernah mendapatkan penyuluhan tentang kesehatan gigi dan mulut dari tenaga kesehatan. Menurut Herijulianti, dkk (2002) media merupakan alat atau sarana untuk menyampaikan pesan kepada sasaran atau orang yang di tuju, bisa melalui media massa (surat kabar, majalah, radio, televisi) maupun media antar pribadi (telepon). Menurut Notoadmodjo (2007) mengatakan bahwa pengetahuan umumnya datang dari pengalaman, juga dapat diperoleh dari informasi yang disampaikan guru, orang tua, buku dan surat kabar. Sedangkan pengetahuan adalah hasil penginderaan manusia atas hasil tahu seseorang terhadap obyek melalui indera yang dimilikinya. Setelah di beri penyuluhan tentang cara menyikat gigi dengan media poster murid kelas I, II, III Madrasah Diniyah Takmiliyah Al-Banat Penyengat Olak Kabupaten Muara Jambi pegetahuannya meningkat pada kriteria tinggi (82,35\%) artinya terjadi peningkatan keterampilan menyikat gigi pada murid kelas I, II, III Madrasah Diniyah Takmiliyah Al-Banat Penyengat Olak Kabupaten Muara Jambi.

Hasil observasi cara menyikat gigi dapat dilihat pada tabel 2 menunjukkan bahwa keterampilan menyikat gigi sebelum diberi penyuluhan ada 17 orang murid kriteria baik $25 \%$ dan kriteria kurang baik 51 orang $(75 \%)$ murid, sedangkan keterampilan menyikat gigi setelah diberi penyuluhan menggunakan media poster meningkat, yaitu dari kriteria baik $(25 \%)$ menjadi kriteria baik $(86,76 \%)$. Keadaan ini menunjukkan bahwa adanya peningkatan keterampilan menyikat gigi setelah mendapatkan penyuluhan tentang cara menyikat gigi yang baik dan benar menggunakan media poster. Adapun hal yang sangat baik pada semua murid kelas I, II, III Madrasah Diniyah Takmiliyah Al-Banat Penyengat Olak Kabupaten Muara Jambi $(100 \%)$ menggunakan pasta gigi yang mengandung fluor dan telah memiliki sikat gigi sendiri.

Berdasarkan pelaksanaan kegiatan yang direncanakan dalam pengabdian kepada masyarakat, maka hasil yang dicapai adalah peningkatan pengetahuan dan keterampilan cara menyikat gigi pada murid kelas I, II, III Madrasah Diniyah Takmiliyah Al-Banat Penyengat Olak Kabupaten Muara Jambi tahun 2019. Menurut Maulana (2009) faktorfaktor yang mempengaruhi penyuluhan kesehatan adalah aspek pemilihan metode, alat bantu atau media, dan jumlah kelompok sasaran, artinya untuk mendapatkan hasil dari penyuluhan

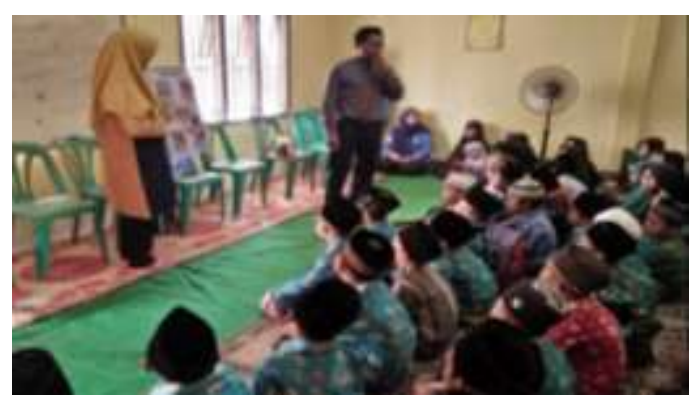

Gambar 1. Pelaksanaan Penyuluhan kesehatan gigi 
yang maksimal ketiga faktor tersebut sangat mempengaruhi. Media yang digunakan ditentukan oleh intensitas media tersebut dalam memberikan pengalaman belajar kepada murid, poster sarat dengan tampilan visual gambar, sehingga lebih melibatkan indera penglihatan murid, apa yang dilihat murid hanya melibatkan $30 \%$ dari indera penglihatan, semakin banyak mengerahkan indera ketika menerima materi penyuluhan maka tingkat penerimaan murid dalam menangkap pesan atau materi penyuluhan akan semakin efektif (Depkes RI, 2008)

Media poster dapat lebih efektif sebagai media penyuluhan karena lebih membantu menstimulasi indra penglihatan murid, aspek visual pada gambar-gambar poster lebih memudahkan penerimaan informasi atau materi pendidikan (Notoatmodjo, 2012).

Efektifitas penggunaan poster dalam penyuluhan kesehatan gigi dipengaruhi oleh ilustrasi gambar, tampilan tulisan yang menarik dan tema poster yang singkat dan mudah dipahami, sehingga memudahkan responden dalam memahami isi pesan poster dan memotivasi responden untuk menyampaikan isi pesan dari poster yang dibacanya kepada orang lain. Luaran yang dicapai adalah peningkatan pengetahuan dan keterampilan cara menyikat gigi pada murid Kelas I, II, III Madrasah Diniyah Takmiliyah Al-Banat Penyengat Olak Kabupaten Muara Jambi.

\section{KESIMPULAN}

Setelah dilakukan kegiatan pengabdian masyarakat, terjadi peningkatan pengetahuan tentang cara menyikat gigi pada Madrasah Diniyah Takmiliyah Al-Banat kriteria tinggi sebelum diberi penyuluhan sebesar 29,41\% menjadi $82,35 \%$ setelah diberi penyuluhan dengan media poster. Adanya peningkatan keterampilan cara menyikat gigi pada Madrasah Diniyah Takmiliyah Al-Banat dengan kriteria baik 25\% menjadi 86,76\% setelah di beri penyuluhan dengan media poster.

\section{UCAPAN TERIMA KASIH}

Ucapan terimakasih kepada Kepala Madrasah Diniyah Takmiliyah Al Banat Penyengat Olak Muaro Jambi dan berbagai pihak yang telah membantu dalam penulisan artikel ini. Terimakasih pula kepada tim reviewer Jurnal Pengabdian Masyarakat Kesehatan atas saran, masukan untuk penyempurnaan tulisan ini.

\section{DAFTAR PUSTAKA}

Depkes RI (2008) 'Pengembangan Penyuluban Kesehatan Melalui Media Cetak, Pusat Promosi Kesehatan', Jakarta (Diakses tanggal 15 februari 2013).

Fitriani,S. (2011) 'Promosi Kesehatan', Graha Ilmu, Yogyakarta.

Handayatun N.H., Kayo N.K., Riyadi S., Fitria K.T., (2020) 'Optimal Concentration of Food Coloring as Plaque Detector', Pakistan Journal Medicine and Health Science Vol. 14, NO. 2, April - Juni 2020

Herijulianti, E., Indriani, T.S., Artini, S., (2002) 'Pendidikan Kesehatan Gigi', Jakarta : EGC.

Kemenkes (2018) 'Riset Kesehatan Dasar 2018’ Hlm. $110-111$

Kusumawardani, N. ,Siswanto J., Purnamasari V, (2018) 'Pengaruh Model Pembelajaran Kooperatif Tipe STAD Berbantuan Media Poster Terhadap Hasil Belajar Peserta Didik', Jurnal Imiah Sekolah DasarV olume 2, Number 2,Tabun2018, pp. 170-174

Linasari, (2017) 'Pengaruh Penggunaan Media Poster dan Leaflet terhadap Pengetahuan Siswa SMA di Bandar Lampung tentang Karies Gigi, Jurnal Ilmiah Keparawatan Sei Betik. Vol 13, No 1 (2017),

Maulana, H., (2009) 'Promosi Kesehatan', EGC, Jakarta.

Niska, (2013 'Penggunaan Media Poster Untuk Peningkatan Hasil Belajar Siswa Pada Pelajaran Pendidikan Kewarganegaraan Di Sekolah Dasar, Jurnal Penelitian Pendidikan Guru Sekolah Dasar, Vol.1 No.2 , Tabun 2013

Notoatmodjo, S. (2007) 'Promosi Kesehatan dan Ilmu Perilaku' Rineka Cipta. Jakarta.

Notoatmodjo, S., (2012) 'Promosi Kesehatan Teori dan Perilaku Kesehatan', Rineka Cipta, Jakarta.

Suwelo, I. S. (1992) 'Karies Gigi pada Anak dengan Pelbagai Faktor Etiologi', Jakarta : EGC,I, 15 